\title{
The Tectonically Active Margin of the Western U.S.A.
}

\section{by John C. Crowell}

The mountainous Pacific margin of the U.S.A. has been the site of repeated interactions between the North American lithosphere and plates that have come in against the continent from Pacific Ocean regions to the west. The record of these complex interactions is now overprinted by the presently active divergent plate motions at the head of the Gulf of California, along the San Andreas transform belt, and in the Cascadian convergent zone. Active tectonic realms to the east include the extensional Basin and Range province.

\section{Introduction}

The Pacific margin of the U.S.A. today lies along the join between the North American lithospheric plate and the Pacific and Juan de Fuca plates (Fig. 1). The diverse topography and geology along a broad belt well over a hundred kilometres inland from the coast is the result of the tectonic interaction between these two huge plates, overprinted upon the products of previous plate interactions (see Hamilton, this issue). In fact, along this continental margin, three major styles of plate junction now occur: convergent, divergent, and transform.

On the southeast, plate divergence is responsible for the Gulf of California, which extends into the U.S.A. as the Salton Trough. As the Gulf widens obliquely, associated with active spreading in its sea floor, the Peninsula of Baja California moves relatively northwestward. From near the border with Mexico on northwestward, the San Andreas transform boundary takes over, along which lateral displacements predominate associated with crustal splintering and rising and falling of crustal blocks. The San Andreas transform belt, which includes most of western California, extends from the Salton Sea region to that of the Mendocino triple junction (Fig. 1).

Plate convergence prevails farther north along coastal California, Oregon, and Washington. Along this border the South Gorda and Juan de Fuca plates on the west dip to depth beneath the Coast Ranges, and belts of mountains and valleys and the row of volcanoes surmounting the Cascade Range are the result.

The active coastal margin merges eastward with several other tectonic realms. These include the still-deforming Columbia Plateau, consisting mainly of thick flows of Miocene basalt, and the Basin and Range province that reaches all the way into northern Mexico and that is characterized by extensional tectonics. Previous plate tectonics regimes have left their imprint upon the geology of the Pacific margin and adjacent regions, however, and their effects shine through the recent tectonic overprintings (see Hamilton, this issue).

\section{Divergence in the Gulf of California: the Salton Trough}

Beginning about $5 \mathrm{Nla}$ ago, the East Pacific Rise became so positioned beneath western Mexico that the peninsula of Baja California, consisting of thick continental rocks, was broken from the North American lithospheric plate. This block (Fig. 1) began to move obliquely northwestward parallel to a series of transform faults in the floor of the Gulf between active sea-floor spreading centers. These continental transforms include the Elsinore, San Jacinto and Newport-Inglewood faults of southern California, which are subparallel to the San Andreas fault itself and part of its transform system. The northern end of the Baja Peninsula, therefore, extends well into southern California where it is sliced by these faults between which the blocks are tilted, warped, and folded. For example, between the Elsinore fault and the Pacific Ocean, the block has been tilted so that its western margin is depressed. As a consequence, a prism of Mesozoic and Tertiary strata is preserved along the coast, whereas their equivalents to the east have been eroded away so that only basement rocks are exposed at the surface.

The Gulf of California narrows within the U.S.A. to form the Salton trough, a complex graben now occupied by the Salton Sea with a surface elevation at about $70 \mathrm{~m}$ below sea level. The rugged and steep borders of the trough are defined by faults with large components of dip slip. The summits of bordering ranges lie close to the margins, reaching heights on the west of $3293 \mathrm{~m}$ and on the east of $1163 \mathrm{~m}$. In latest Miocene time before the Salton trough opened, the crust was stretched and the surface sagged so that a marine sea invaded the region. In the Early Pliocene, the Salton trough proper opened, accompanied by regional arching, which is interpreted as the result of thermal expansion of the crust and upper mantle above the northern continuation of the East Pacific Rise.

Rocks on either side of the Salton trough consist largely of ancient granites, gneisses, and schists, now deeply eroded and well exposed in the desert environment. Their structure largely reflects geological events of the Mesozoic and early Tertiary, and only sparse shreds of rocks, now metamorphosed, formed during Mesozoic and early Tertiary displacements (see Hamilton, this issue). On the eastern side of the trough, mid-Tertiary crustal extension is especially documented by low-angle detachment faults between basement and overlying blocks of Tertiary volcanic rocks and nonmarine strata. Late Cenzoic faults and folds, which formed during the opening of the Gulf of California and the Salton Trough, overprint these Miocene and older structures.

Within the Salton trough itself, Pleistocene and Recent strata consist largely of alluvial and playa deposits and are folded and faulted, attesting to ongoing deformation. Sediment carried into the growing trough from the ancestral Colorado Rivers (Fig. 1,) forms the bulk of the fill, which beneath the Salton Sea is over $6 \mathrm{~km}$ thick, as shown by deep seismic profiling. Active spreading centers are inferred to lie at depth, because volcanoes have erupted here during the last few hundred years. Gravity studies indicate dense rocks, probably upper mantle material, at relatively high crustal levels.

The region is now hot, with thermal gradients so high that at places there are geothermal power plants. Pleistocene sediments are undergoing metamorphism, and greenschist facies minerals, including sulfides, are recovered from deeper wells. Geodetic measurements and first-motions on frequently recurring earthquakes also document the oblique widening of the trough. Several recent earthquakes (1940, 


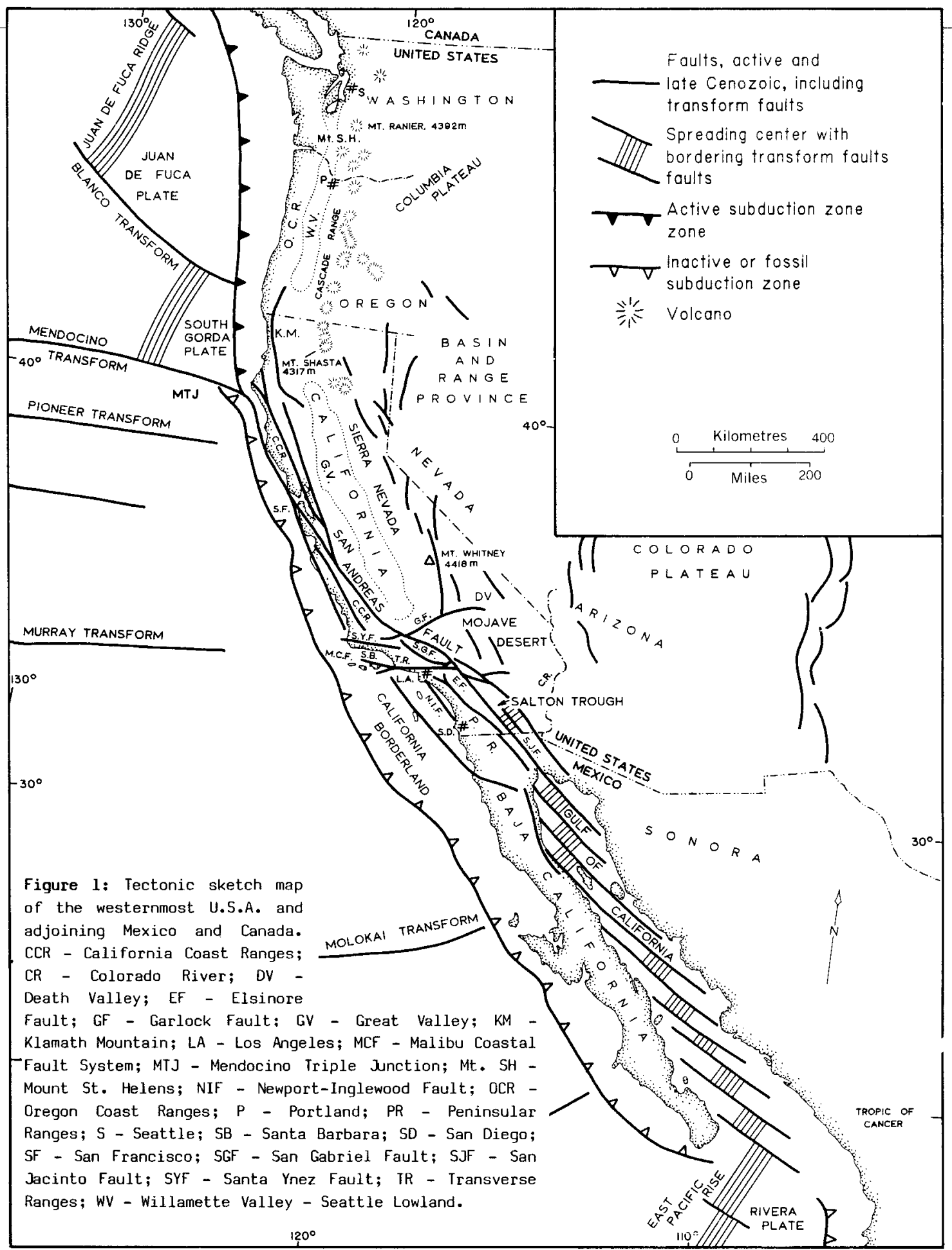

1979) have occurred along faults, breaking the surface and offsetting highways and irrigation ditches. Agricultural areas have sagged so that irrigation water has become ponded. The combination of topographic, geological, and geophysical observations document the concept that pullapart basins are actively forming today as the Salton trough widens.

\section{The Farallon Plate and the Transverse Ranges}

Near the end of the Oligocene Epoch, the Pacific lithospheric plate had moved relatively eastward to impinge against the margin of the North American plate. The event was heralded by the thinning and fragmentation of a wide region as the East Pacific Rise abutted against the continent. Earlier, the intervening and previously existing Farallon plate was being subducted eastward beneath the North American plate (see llamilton, this issue, Fig. 3). The sear of this ancient and now abandoned subduction zone lies near the base of the continental slope south of the Mendocino triple junction (Fig. 1).

When the Pacific plate reached the North American plate it split into two, and the San Andreas transform was born. Through time, as the two triple junctions moved apart, the San Andreas transform system both lengthened and widened. The northern part of the Farallon plate remains today as the South Gorda and Juan de Fuca plates, and the southern as the Rivera plate (Fig. 1). Much of the 
topographic and tectonic style of western California is the consequence of this widening of the mobile belt through time.

The Salton trough narrows on the north where it meets the Transverse Ranges (Fig. 1), which consist of a set of mountains, largely with east-west trends, lying athwart the prevailing trend of topographic and tectonic units of westernmost North America. Long faults within the Peninsular Ranges, such as the Newport-Inglewood and Elsinore, reach northward and impinge against them.

The rocks within the Transverse Ranges reveal a complex and long but discontinous history, extending back in time even into the Proterozoic Era. It is only within the last million years or so, however, that these mountains, which consist largely of continental rocks of North America, have been uplifted. Deep erosion now exposes the older rocks including tectono-stratigraphic terranes that are exotic with respect to adjacent terranes on the east. Many of the former are interpreted as having travelled long distances by sea-floor spreading processes and as now accreted to the continent. However, an adequate tectonic explanation for the anomalous trend of the Transverse Ranges is still lacking.

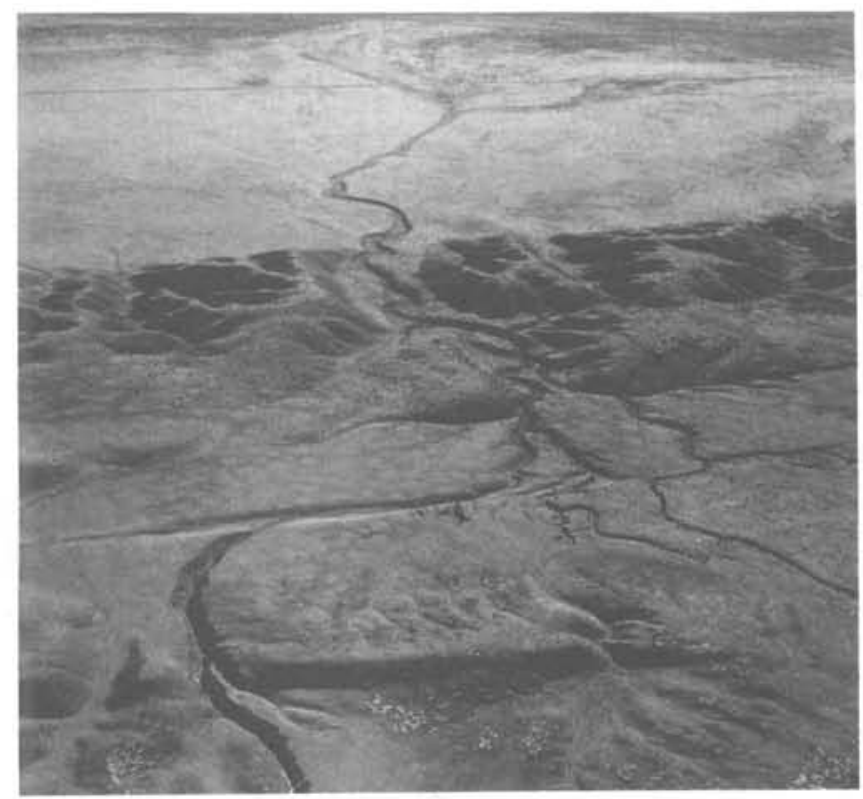

Figure 2: Fault scarps and displaced drainage along the San Andreas fault zone, Carrizo Plain, central California looking eastward. Photo by R.E. Wallace.

\section{The San Andreas Transform Belt}

Many faults bordering and within the Transverse Ranges are active; these include members of the San Andreas system. The trend of the San Andreas itself is more westerly through the ranges than elsewhere, and in the north-central part of the Transverse Ranges it has an east-west course in the region known as the "big bend" near its intersection with the Garlock fault (Fig. 1). The San Andreas and San Jacinto faults cut into the Range on the south, but the Elsinore and Newport-Inglewood do not; they abut against it.

The Malibu Coastal fault zone, one of the most complex and enigmatic in California, forms the boundary between the Transverse Ranges and the Peninsular Ranges on the south. This belt, which is inferred to have been reactivated at least three times since the mid-Tertiary, is now largely a thrust or reverse fault zone along which the mountain ranges have been recently uplifted. It and faults of similar trend, such as the Santa Ynez (Fig. 1), are involved in the tectonic and topographic pattern in the offshore region near Santa Barbara where the Transverse Ranges structures plunge beneath the ocean. Tectonic blocks within the Transverse Ranges, and some in bordering regions, have been rotated more than $90^{\circ}$ clockwise, as shown by studies of paleomagnetism reinforced by geological observations. The rotations occurred mainly during the Middle and Late Miocene as the tectonic blocks and slices were caught up and spun about in the simple-shear scheme of the San Andreas transform belt.

The California Borderland (Fig. 1) lies west of the Peninsular Ranges, the Transverse Ranges, and the southern part of the California Coast Ranges. The bathymetry in this offshore region is irregular and the tectonics fragmented. The region consists of deep isolated basins with a few islands protruding above sea level. Faults of both dip-slip and strike-slip displacements outline high-standing lenticularand rhomboid blocks and separate them from basins. A similar tectonic style and topographic character extends to nearby onshore regions. Here basins are filled with sediment because they are close to high-standing source areas in the mountain ranges along the continental margin.

The Los Angeles basin, for example, is interpreted as a deep pull-apart basin with complex substructure, similar in origin to the Salton trough. In its deepest part, the top of the Miocene lies at a depth of $6 \mathrm{~km}$. It is now filled to form a broad plain upon which Los Angeles sprawls. The predominantly marine sediments within it are Neogene and Quaternary in age, and were first deposited as the basin opened in the Early Miocene and then compressed and deformed during the Pleistocene at the same time as the Transverse Ranges were uplifted. The Los Angeles basin contains about 12 billion barrels of recoverable petroleum, and is one of the most prolific oil provinces for its size in the world. Other oil basins in California, both onshore and offshore, have a similar evolution, developing concurrently with both sedimentation and deformation.

Through the Transverse Ranges and central California, the San Andreas system consists of many subparallel faults, several of which are now active. However, others, such as the San Gabriel fault (Fig. 1) were born in Miocene time, and have now been abandoned as major movement zones responding to the present plate-tectonic scheme. Tectonic blocks and slices between the faults have been jostled, tipped and rotated, with some long blocks squeezed upwards to form mountain ranges and others depressed to form valleys. Studies of the rock mismatches and correlations across faults show that some blocks have been moved laterally for many kilometres within the mobile scheme. Nonetheless, the tectonic pattern that prevailed in California before fragmentation and dispersal within the San Andreas transform belt can largely be reconstructed.

California is earthquake country, and many of the earthquakes occur along faults within the broad San Andreas transform belt. Among these are the San Francisco Earthquake of 1906 and several of lesser severity that can be related directly to displacement on the San Andreas fault itself. The Parkfield Earthquake of 1966 occurred on this fault, and a recurrence of another moderate-magnitude earthquake is expected in this same region within the next year or so (see Filson, this issue). Other earthquakes, however, are along deeper faults, which do not crop out.

The Coalinga Earthquake of 1983 resulted from displacements on hidden faults at depth, with motions athwart those of San Andreas displacements. In this region of the central California Coast Ranges, shortening across the transform belt is taking place nearly at right angles to the trend of the San Andreas. This is shown not only by the first motions on earthquakes, but also by the orientation of growing folds. The San Fernando Earthquake of 1971 is conceptually related to the impingement northward of the Peninsular 
Ranges against the Transverse Ranges. Farther afield from the San Andreas belt, earthquakes, such as the severe Owens Valley Earthquake of 1872 , was related tectonically to the obliquely widening Basin and Ranges Province. Fault landforms are conspicuous along many of California's faults and not only those of the San Andreas system (Fig. 2 and see Fig 1, Filson, of this issue).

\section{The Cascadian Convergent Belt}

North of the Mendocino triple junction, the South Gorda and Juan de Fuca plates are moving relatively eastward and downward beneath the continental rocks of North America. Tectonic and topographic features on the continent to the east of the subsea subduction zone are related to this tectonic style. The uplifted Coast Ranges of northernmost California, Oregon, and Washington and the broad depression occupied by the Willamette Valley - Seattle Lowland (Fig. 1), and especially the row of high volcanoes surmounting the Cascade Range, fit into this pattern. Mt. Rainier, the highest dormant voleano $(4392 \mathrm{~m})$, and Mt. St. Helens, violently active in 1980, are members of this group. As the Mendocino triple junction moved northward during late Cenozoic time, the belt of convergence moved with it so that the track of volcanic centers cut off in their activity by these movements is recognized to the south in California.

\section{Inland Tectonic Realms}

Active tectonic and older belts occupy the central and eastern parts of Washington, Oregon, and California and adjoin and overlap with the active plate divergence, covergent, and transform displacements (see also Hamilton, this issue). The Sierra Nevada, the highest range in the United States, consists of an uplifted and tilted composite fault block at the eastern border of the Basin and Range province (Fig. 1). The latter is a broad region of extension, consisting of tilted blocks between predominantly dip-slip faults, many of which have significant components of strike slip. Death Valley, with an elevation of $86 \mathrm{~m}$ below sea level, and the lowest place in North America, lies within a rugged region only $150 \mathrm{~km}$ from $\mathrm{Mt}$. Whitney $(4418 \mathrm{~m})$, the highest peak in the conterminous U.S.A. (Fig. 3). Other inland tectonic realms include the Columbia Plateau and the Colorado Plateau (Fig. 1).

\section{Tectonic Development of the Westernmost U.S.A.}

Rocks of these tectonic realms, both inland and along the Pacific margin, reveal several distinct deformations and orogenies (see Hamilton, this issue). Late Precambrian rifting is well exposed in southeastern California in the Death Valley region, associated with thickening westward of deposits of passive-margin type. Paleozoic events, such as the Devono-Carboniferous Antler orogeny and the PermoTriassic Sonoma orogeny have left their mark, especially in western Nevada. From the Late Triassic to the Late Jurassic, subduction accompanied by the emplacement of magmatic ares took place in California and adjacent regions and is now under investigation in the northern Sierra Nevada and Klamath Mountains.

The record from Late Triassic time onward into the early Tertiary is particularly complete. This is the time of Fransciscan subduction when mélanges, now widely uplifted and exposed in coastal ranges, were emplaced; these are now associated with accretionary slices and deposits. Synchronously with these subduction mélanges are fore-arc basin deposits of the Great Valley sequence of California, and similar deposits in Oregon and Baja California. In a belt east of the fore-are deposits, lie remnants of magmatic arcs, now largely uplifted and deeply disected. In the Sierra Nevada, for example, the prevailing rock type is Cretaceous granitic rock emplaced originally as the foundations of these arcs. Farther east, and trending obliquely into the San Andreas system in southeastern California, are several belts of Mesozoic and early Tertiary thrusting and associated deformed rocks. These belong to Jurassic systems, and to the Cretaceous Sevier, and the Cretaceous-Paleogene Laramide systems.

Evidence is now coming to light supporting the concept of far-travelled blocks, carried into the Pacific margin of North America from distant sources within the Pacific Ocean and from around its borders, and sutured to the continent. Blocks are now annealed to the continental plate along sutures that are either mylonitic fault zones or collision belts. Paleomagnetic and stratigraphic data support the concept that some terranes now adjacent originated at vast distance and have subsequently been brought into juxtaposition by seafloor-spreading and transform processes. Research is focused on documenting these tectonostratigraphic terranes and in tracking their paths through geological time to their present docking positions as part of North America. Today these terranes, joined to the continent by ancient suturing processes, are being sliced off again within the active tectonic belt and are being carried northwestward by transform displacements related to the interaction between the Pacific and North American lithospheric plates (see Stone and Wallace, this issue).

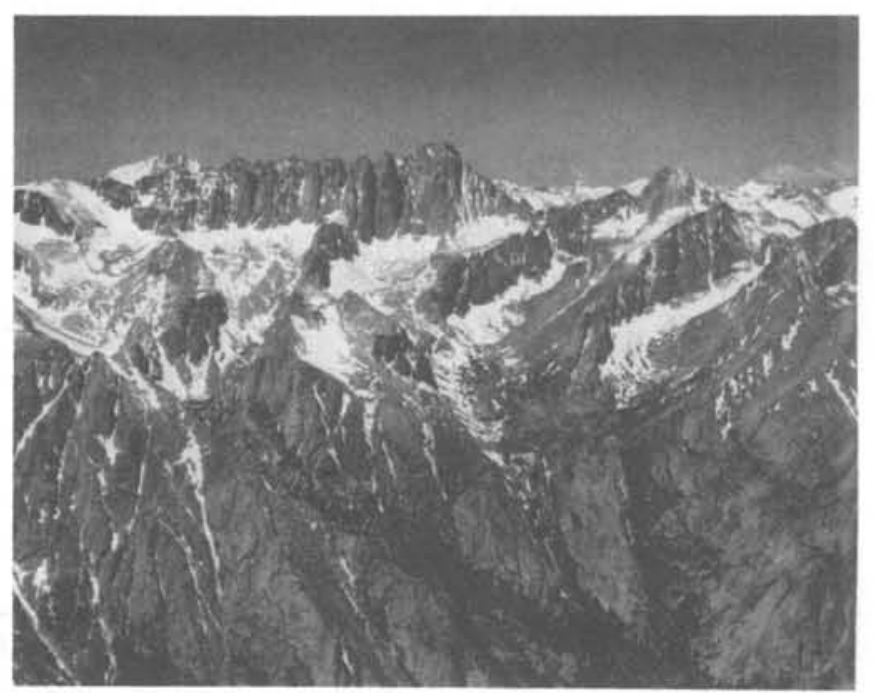

Figure 3: Mt. Whitney and crest of Sierra Nevada, east-central California looking westward. Photo by J.C. Crowell and J.S. Shelton.

In Miocene time, much of the Basin and Range province and adjacent areas was extended and dismembered. Low-angle detachment faults are conspicuous in the desert regions of southeastern California and nearby parts of Nevada and Arizona. Blocks above detachment faults, consisting mainly of non-marine strata and volcanic rocks, are tipped and rotated, much like fallen dominoes. These faults are gently undulatory on a regional scale, and several pass into basement terrane beneath the displaced Tertiary rocks above.

Deep reflection seismic studies document regional extension between lensoid blocks separated vertically by thick mylonitic zones. At places extension has proceeded to the extent that mid-crustal rocks are exposed in gneissic core complexes. Shallower rocks above these have been carried away laterally to their margins and the deeper rocks uplifted to view. Extension in much of the Basin and Range province is still continuing today. In the Death Valley region, and farther to the south and west, strike-slip displacements with orientations similar to those of the San 
Andreas transform belt, suggest transitions and interrelations between the extensional province and the transform belt.

\section{Summary}

The geology and topography of Washington, Oregon, and California are the result of a long history of tectonic activity along the western margin of the North American lithospheric plate. The piecemeal record shows that many plates from Pacific Ocean regions have interacted with this margin in many ways. The present tectonic activity and the shape of the landforms, however, are the result of plate divergence in the Gulf of California reaching into California on the southeast, of the San Andreas transform belt continuing northwest to the Mendocino triple junction, and the Cascadian convergent belt that extends on north to Canada.

Farther inland, and especially in the Basin and Range province, extensional deformation is also conspicuous in the landforms today. Throughout the westernmost U.S.A., earthquakes and active crustal deformation overprint a complex record of continental accretion, and fragmentation and distortion, associated with ancient episodes of convergent, divergent and transform displacements. Recent deformations overprint older, and similar overprintings have occurred again and again back in time as far as the record ean be deciphered.

Dr. J. C. Crowell, is Professor Emeritus at the Institute for Crustal Studies, University of California, (Santa Barbara, CA 93106 , U.S.A.) He has studied the displacement history of the San Andreas fault system, the tectonics of southern California, the sedimentation history of transform basins, turbidity current deposits, and the global record of ancient glaciations.

\section{Additional Reading}

Armentrout, J.M., Cole, M.R. and TerBest, H., Jr. (eds.), 1979. Cenozoic paleogeography of the western United States. Pacific Section, Society of Economic Paleontologists and Mineralologists, Los Angeles, California, 335p.

Drummond, K.J. et al., 1981. Plate-tectonic map of the Circum-Pacific region, northeast quadrant. American Association of Petroleum Geologists.

Ernst, W.G. (ed.), 1981. The geotectonic development of California. Prentice-Hall, Inc., Englewood Cliffs, New Jersey, $706 \mathrm{p}$.

Frost, E.G. and Martin, D.L. (eds.), 1982. MesozoicCenozoic tectonic evolution of the Colorado River Region, California, Arizona, and Nevada. Cordilleran Publishers, San Diego, California, $608 \mathrm{p}$.

Howell, D.G. (ed.), 1985. Tectonostratigraphic terranes of the Circum-Pacific Region. Circum-Pacific Council for Energy and Mineral Resources, Earth Sciences Series, No. 1, Houston, Texas, 585p.

Howell, D.G. and MeDougall, K.A. (eds.), 1978. Mesozoic paleogeography of the western United States: Pacific Coast Paleographic Symposium, No. 2. Pacific Section, Society of Economic Paleontologists and Mineralogists, Los Angeles, California, 573p.

Ingersoll, R.v. and Ernst, W.G. (eds.), 1987. Cenozoic basin development of coastal California. Prentice-Hall, Inc., Englewood Cliffs, New Jersey, 496p.

\section{WVIE ARIE STACIRED WITIBI GRIEAT TITLLS}

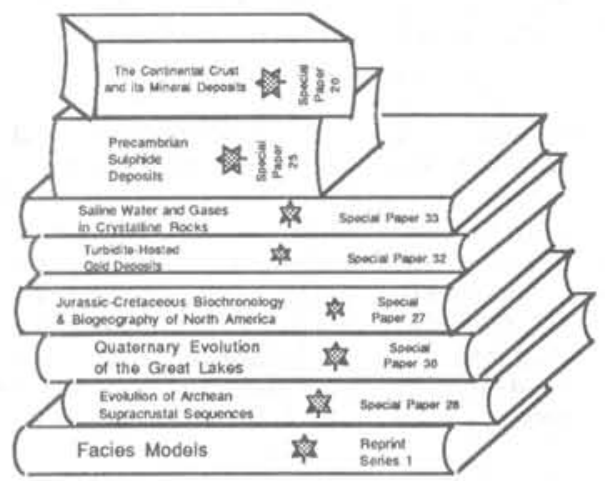

GEOLOGICAL ASSOCIATION OF CANADA ASSOCIATION GÉOLOGIQUE DU CANADA

Department of Earth Sciences, Memorial University of Newtoundiand St. John's, Newfoundland, CANADA, A1B JXS Phone (709) 737.7660

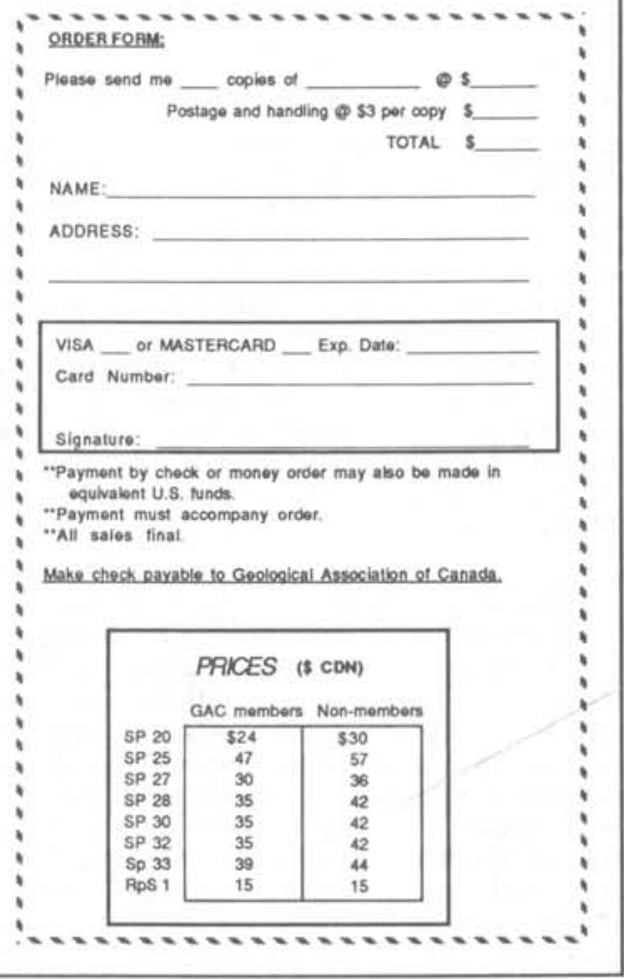

